\title{
The choice of coalition governments for promotion of national unity in Africa: Does the model work for unity and political stability?
}

\author{
Kananelo M. Sekatle \\ Mokoko P. Sebola \\ University of Limpopo, South Africa
}

\author{
Keywords \\ Coalition, Coalition government, National unity, Political stability
}

\begin{abstract}
The purpose of this paper is to argue that coalition government is not able to achieve peace and stability in African governments as envisaged through political solutions. The paper therefore evaluates the effective use of the coalition model in political stability and promotion of national unity. The paper is conceptual in approach and it uses a desktop method. A coalition is a group of organisations or political groupings that come together for the purpose of gaining more influence and power than the individual organisations can achieve on their own. There are numerous African countries that have adopted the coalition government model for political compromise and stability in their government. The intention is to find out whether the model is practically effective because the model has both advantages and disadvantages. The paper concludes that coalition model is not suitable for the African context. It has shown to fail in numerous countries where it was tried.
\end{abstract}

\section{Introduction}

Where instability characterised the political environment in Africa, coalition government have been formed as a short-term solution. The purpose mainly has been to assure the society of the spirit of national unity within a country. In South Africa, the Transitional Constitution was adopted in 1993 lead by the then president Nelson Mandela through the government of national unity established with the apartheid architect, the National Party which ended in 1994, April 27, when the African National Congress won the majority votes in the first national democratic elections (SAHO, 1994:1). In Zimbabwe when the Movement for Democratic Change (MDC) challenged the three-decade rule of the ZANU-PF and president Robert Mugabe, a government of National Unity was formed by president Robert Mugabe sharing power with MDC president Morgan Tsjangirai (Idasa, 2008:2). In Lesotho such happened when All Basotho Convention (ABC) formed by prime minister Thomas Thabane was joined by Lesotho Congress for Democracy (LCD) and Basotho National Party (BNP) in coalition. The LCD was founded by Ntsu Mokhehle and is currently led by Mothejoa Metsing, the Basotho National Party(BNP) was found by Leabua Jonathan and is led by Thesele Maseribane, Lesotho was first governed by a coalition government in 2012 (Motamai, 2012:1). The question raised in this paper is whether the coalition model in African governance has ever effectively promoted national unity as espoused? Indeed, where it has been attempted no good results were achieved. In arguing for the effectiveness of the coalition model in achieving national unity, the paper will focus on understanding the nature of coalition governments, models of coalition government, strengths and weaknesses of coalition governments and whether coalition government lead to unity and political stability?

\section{Understanding the nature of coalition governments}

A coalition government is a cabinet of a parliamentary government in which several parties come together to form a unity government (Henry, 2009:149). On the other hand, Cheibub, Przeworski and Saiegh (2004:565) define coalition government as a group of legislators that belong to different parties that hold cabinet posts. The main reasons for this kind of arrangement is because there is no party that can achieve majority on its own in parliament. In a bi-party system, a dead lock may be created because the votes will even be among competing parties which leave the parties with no alternative except working together as a collective. A coalition government can also be formed in cases whereby there is a national crisis such as in time of war. Such arrangement grants the government some degree of legitimacy (Henry, 2009: 149). 
Coalition governments are possible as adopted by either the presidential or parliamentary system of government. In the presidential system, the popularly elected presidential candidate forms a government with cabinet members mainly drawn from his or her political party. This is because the presidential system is a unilateral act, however, the president may invite members of other parties as well (Japeth, 2008:19). However, in the parliamentary system, the party with most seats in parliament forms government and the leader of that party becomes the prime minister or the head of government. In case of parliamentary system, a coalition government results from formal negotiations among political parties in a country (Japeth, 2008:19).

These types of governments advocate for representation and it is believed that coalitions lead to more consensus-based decisions. The government which is composed of diverse parties that have different ideologies would have to agree in regard to governmental policy decisions (Shodhganga, 2005:25). Adoption of a coalition government is a means of managing conflict and bringing about unity, which stems from the consociation (democracy) in divided societies (Kisobo, 2013:10). Coalitions are often designed to prevent the common enemy attaining power, and the system promotes representatives of diverse society. They result in accommodative politics that are also characterised by compromise, in which small and less powerful parties get an opportunity to voice their opinions in government and in public policy making. Furthermore, it provides for the majority of the electorate to be represented (Jacob, 2002:9). Coalitions also denote consensus. For decision-making process to take place, all partners ought to be consulted for consensus to be reached. If all the partners obey this principle of consensus, the coalition is likely to be more viable than a single-party majority, because with time the coalition would absorb the ideas and wisdom from different parties. Decisions that are made through consensus tend to carry more weight, due to the fact that they reflect the opinions of more than one actor (Tiwana, 2001:131). The stability of a coalition is also highly dependent on the equality of leadership, be it government or in the opposition (Jacob, 2002:10). In general, for coalitions to be a success, there must be a political force that is entitled to respect and allegiance due to the reliability of its political theory. Ideological homogeneity must be existent and a well-established leadership that is characterised with a common goal as well as being on the same wavelength with the central force (Raman, 2001:211).

\section{Models of coalition government}

As mentioned above, coalitions are formed for different reasons and are also formed in different kinds of systems or even under different kinds of circumstances. In this case, two categories of coalition governments are explained, namely classical coalition and consociational coalitions. These models differ in approaches.

\section{Classical coalition governments}

These are the type of coalitions formed mainly to attain parliamentary majority. Oguyi (2006:54) states that the formation of coalitions is usually the display of the absence of a dominant party that is capable of the governing. Elections play a vital role in formation of classical coalitions. Consequently, a government can be formed before or after the elections and this gives rise to the two types of classical coalition governments: the pre-electoral and the post-electoral (Japeth,2008:19). They are traditionally contained by political parties and elites for political convenience (Majeed, 2000:3).

\section{Pre-electoral coalitions}

This is a coalition model whereby different candidates are competing for a single office in which some candidates come together to form a coalition prior to the elections. Candidates who usually form elections are those who are both office and policy motivated. One candidate has to encourage the other to withdraw their candidacy by choosing a joint policy platform (Shin, 2018:162). Pre-electoral coalition is defined by Golder (2006:195) as a situation where various parties' co-ordinate their electoral strategies rather than running for the office individually. Pre-electoral coalitions are likely to be formed by ideologically compatible parties. Parties usually resort to this type of coalition with the hope that they stand a better chance to win when they work collectively. Pre-electoral coalition governments have been witnessed in Mauritius and Kenya (Mutakha, 2007:109). In Kenya a coalition of six parties was formed with the aim of unseating the Jubilee party lead by Uhuru Kenyatta. The six parties were, the Orange Democratic Movement (ODM), the Wiper Party, the Amani National Congress, Chama cha Mashinani, the 
Nark Kenya Party, the United Democratic Party and the Muungano Party (Kimani, 2017:1). On the other hand, Sithanen (2003:2) states that Mauritius has always been governed by a coalition government ever since it gained its independence. In Mauritius, the formation of coalitions is influenced by the officeseeking strategy more than other factors. For instance, Mouvement Militan Mauricien (MMM) joined forced with Movement Socialiste Mauricien (MSM) in order to ensure political victory (Sithanen, 2003:7) These parties came together to form a coalition before the elections could be held and this makes their alliance a pre-electoral one.

\section{Post-electoral coalitions}

In most cases, post-electoral coalitions are formed when the classical coalitions fail. They often fail when the ruling party is unable to return from the elections with majority of parliamentary seats. In this instance, the ruling party is forced to invite the opposing party in forming the government (Laver and Budge, 1992:15). If it was not for the shortage of seats in parliament, the ruling party would not be forced to form a coalition with an opposing party. In countries where the model of coalition governments is adopted, the political actors always resort to the formation of coalitions after the elections. This formation does not reflect the preferences of the voters whereas the pre-electoral coalition does (Laver and Budge, 1992:16). Examples of post-electoral coalition countries include, Malawi after the 1994 elections, and Lesotho following the 2012 elections. The post-electoral coalition was formed in Lesotho due to a hung parliament that was produced by the elections. The three parties which came together to form a coalition are All Basotho Convention (ABC), Lesotho Congress for Democracy (LCD) and Basotho National Party (BNP) (Kapa and Shale, 2013:93).

\section{Consociational coalition governments}

Consociational government is defined as a "stable democracy in deeply divided societies" (Andeweg, 2015:692). Consociational coalition governments are meant to ensure stability through accommodating different segments of a deeply divided society and can also be prescribed when democracy is at risk due to social segmentation (Lijphart, 2004:98). This kind of coalitions are meant to aggregate the interests and demands of the diverse groups. These interests and demands can be met through the creation of a power sharing framework (Kisobo, 2013:18). The power sharing framework should allow the minority groups some autonomy over certain aspects of their own so that they can also get some sense of belonging. This will reduce conflicts that arise due to power imbalances among the diverse groups (Sisk, 1999:37).

Sisk (1999:36) outlines that consociational is composed of four elements such as, grand coalition, group autonomy, proportional representation and minority veto. Grand coalition means all the minority groups have to be included (Lijphart, 2013:93). Group autonomy in consociational asserts that minority can rule over itself, which means it is only in areas of common concern where decision making will take place by consensus. Proportional representation on other hand advocates for the representation of all parties in government (Sisk, 1999:36). Minority veto protects every single party from being voted out during the decision-making process. This type of coalition can be found in countries that are transitioning or have undergone transition. The transition can be from repressive to democratic regimes or from civil war to peace.

Consociational coalition governments started in Africa in the 1960's when countries were transitioning from colonialism to independence. These are said to be the "first generation of coalitions" that became existent prior to independence or immediately after independence (Oyugi, 2006:58). They were created in order to bring about a stable political climate for the former British colonies. Pippa (2008:23) states that power-sharing is one of the most hopeful possibilities to lasting stability and sustainable democracy. For this reason, it is important for political actors to adopt the power mechanisms in order to maintain democracy. More often, coalitions emerge after war and it becomes a settlement. The opponents will always have to see to it that power is not dominated by one group. This is because power sharing provides assurance by guaranteeing every group a slice of power among rival groups. Power sharing institutions reduce the danger of one group dominating and threatening the security of others. Societies that utilise this model would have the ability to exercise power consensually, as well as to regulate conflict within democracies that are characterised by deeply divided societies (Liphart, 2004:97). 


\section{Strengths and weaknesses of coalition governments}

Although coalition governments are seen as mechanisms for bringing unity within societies, coalitions still have some negative effects on societies. Both the strengths and weaknesses are explained below.

\section{Strengths of coalition governments}

Generally, coalitions are seen as significant in promoting homogeneity, aggregating policy preferences, promoting representation, sharing of resources and preventing domination.

\section{Promotes homogeneity}

Coalition governments advocate for homogeneity; and are formed with ministers that are drawn from diverse political parties. The arrangement therefore represents different and contradictory viewpoints of the same group (Essays, 2013:6). Such also allow smaller parties to improve their public profile and also to exercise their disproportionate power by participation in government as kingmakers in legislatures that are hung (Stiftung, 2018:26). Coalitions create stable political climate within deeply divided societies. They promote political stability in legislatures whereby there is no party that has won majority seats and there are numerous competing parties (Kadima and Lembani, 2006:138). In a case whereby no party has won the majority seats, coalition is the solution because political parties have to ensure the electorate that a stable government will be existent and the needs and demands of the people will be attended to.

Aggregation of policy preferences

Coalitions governments consist of different members with different policy preferences, and it is easier to achieve acceptance of policy reforms that it is in homogeneous government. Reason being, difference in policy preferences provides guarantee protection against reform proposals that are biased towards the interest of a particular party (Helm and Neugart, 2013:384). For instance, coalition governments bring about representation of the political, social and economic aspiration and needs of numerous regions and sections of society (Bhatia, 2003:143).

Representation

A broader spectrum of people and a wider range of views are represented in coalition governments and this makes coalitions to be more democratic and fairer. Thus, they tend to have smooth continuity in administration because of their representative nature (Oxbridge Applications, nd). Due to different preferences that are existent in coalitions, policies are usually debated in which numerous viewpoints are considered before a policy can be implemented. Also, because of greater policy inspection in coalition governments, policies are usually beneficial to the larger portion of the electorate than it is the case with single party government.

Evenly shared resources

Coalition governments are regarded as an important way of increasing power and stretching of resources. The stretching of resources on other hand helps to overcome deficiencies (Higgins, 2014:35). They also have the benefits of national unity, homogeneity and channelled information. The parties are also able to share campaign costs in coalitions that are pre-electoral (Dhillon, 2003:5). They also bring about political stability and spur the economic and social development as well as re-establishing democracy. For example, in a case whereby conflict has occurred in plural societies, a coalition government can be adopted as way of reviving democratic governance (Karume, 2003:2).

Prevents dominance

According to World animalnet (nd), coalitions assist in overcoming the fear of dominance of large parties over small parties. This is because they provide protection for members who are unable to take action alone. The coalitions make it is easier to achieve more together in which one individually "win together what you cannot win alone". Coalitions increase the base of support for government, as well as the base of networks and connections. 


\section{Weaknesses of coalition governments}

The strengths of coalitions cannot be seen outside the context of its weaknesses. Its known weaknesses are hindrance to accountability, threat to unity, promotion of a particular party policy, delegation risk and compromise and public expenditure.

\section{Hindrance to accountability}

Single party governments are usually thought to be more responsible for government policies than coalition governments. This is because it is difficult for coalition governments to be held accountable for their past actions, which hinders governments capacity to enforce accountability (Hobolt and Fisher, 2010:358). In coalition governments parties are not held accountable due to blurred lines of responsibility within the multi-party operation. In a case where accountability is hindered, the citizens are unable to sanction the government for its actions (Anderson, 2000:152). Moreover, if there is no party to be held accountable in a coalition government, the parties will not feel the need to fulfil their responsibilities.

\section{Threat to unity}

According to Horowitz (1991:100), coalition governments in the case of consociational democracy perpetuates the very same divisions that it is meant to eradicate. The model leads to racially or ethnically defined majorities and minorities. Although Sisk (1999:36) states that consociational coalition government is characterised by minority veto, minority parties still feel some sense of under-representation. Coalitions often end up being unstable (Booysen, 2015:430). Unstable coalitions are also a result of powerful parties acting in an oligarchic manner which makes the alliance stifle and also make it hard for the minority parties to grow.

\section{Promotion of a particular party policy}

Martin and Vanberg (2004:13) argue that the policymaking process by coalition governments generates a classic principal-agent problem. Coalitions are composed of different parties that have different preferences. Therefore, there are high chances for ministers to focus on policies that favour their own policies at the expense of their coalition partners. Having ministers pursue policies of their own parties will lead to a hostile relationship between parties and this can result in political instability that can even force change of government in some instances. For example, Lesotho has been experiencing unscheduled elections ever since the coalition government was adopted in 2012 (Booysen, 2015:430). Unscheduled elections are taking place regularly in Lesotho because the ministers tend to prioritise policies of their parties and neglect those of the coalition. Coalition governments also tend to be fractious and are inclined to disharmony because of the different ideologies of each party (Shodhganga, 2005:25).

\section{Delegation risk and compromise}

The problem of delegation is also existent in this system of government. Delegation creates the risk that minsters might truly not work in the interests of the main principle. In other words, for coalitions to be formulated, the leaders must be willing to compromise (Martin and Vanberg, 2004:14). In most cases, the political leaders are not always ready to make compromises, therefore, they end up undermining policies that have been agreed upon and moving government policies to the direction they prefer. Coalition government have also been criticised for pursuing consensus even though a disagreement would be more fruitful in some instances. Political leaders of these kind of governments tend to force consensus because they are trying by all means to unify the coalition against the opposition (Martin and Vanberg, 2004:13). Forced consensus can result to other issues that needed to be attended to unresolved, because the political leaders end up shifting their focus on the unity of coalition more than attending to the interests and demands of citizens. Another issue is that coalitions are hard to hold together and the party leader end up colluding.

The more diverse the parties are, the more it gets difficult for the government to attend to the interests and demands of the citizens. Coalition governments are usually characterised by the delay of policies (Martin and Vanberg, 2004:18). Irrespective of parties being diverse, coalitions are likely to be characterised with delayed policies because the decision making is not as simple as it would be with a single-party government. The delay will happen because to many leaders ought to be informed and there is also the red tape that has to be followed, as a result policy implementation process will be delayed. 


\section{Public expenditure}

Another challenge faced by coalition is the fragmentation that increases public expenditure (Baskaran, 2013:356). This is because majority of parties tend to use their position and government resources, to campaign for the coming elections. Instead of parties focusing on the priorities of the citizens and governing them, they focus on polls, and this will not lead to any development, instead, development is hindered (Matjama, 2013:1). Coalitions always lead to increased expenditure because the budget is hardly used on what it was meant for, due to the fragmentation.

\section{Can coalition government lead to unity and political stability?}

Matjama (2013:10) also states that coalition governments are usually fragile, especially in cases where parties forming a coalition have the slimmest of majorities in parliament. This simply means any defection could cause the government to lose control of the assembly. Lijphart (2004:99) outlines that in a deeply divided society, the total number of votes received by each political party tend to be very low as a result of the division within the society. Thus, political parties' resort to forming coalition so as to secure as many votes as possible (majority seats). It is therefore sensible to assume that in a deeply divided society, formation of a coalition might be seen as a reasonable solution for the society. However, Rabushka and Shepsle (1972:335), argue that democratic elections lead to instability in a divided society since the politicians belong to different ethnic groups that are more focused on outbidding each other, therefore social tensions are strengthened.

Vowels (2010:370) argues that there are slim chances for coalition governments to bring about change unlike single-party governments. This is because coalitions are composed of numerous actors who need to agree on policy innovations, and due to this, coalitions are linked with fewer policy differences. There are fewer policy differences in coalition governments because it takes longer periods for decisions to be reached due to a large number of actors that have to be informed unlike in single-party governments. Thus, the principle of governments ought to "make a difference" will be weaker under coalitions than in single-party governments. Just like minority governments, they need support from opposition parties in order to pass legislations, therefore it is highly impossible for them to deliver on their commitments (Vowels, 2010:370).

Timmermans (2003:4) describes coalition agreements as "incomplete contracts", because not like commercial contracts, they are not regarded as legally enforceable, coalition contracts have too many loopholes. This is because there are few mechanisms that can restrict coalition partners from dishonouring the partnership (Moury and Timmermans, 2013:118). For this reason, coalitions tend to lead to government instability due to the limited mechanisms that can be employed for coalition partners to comply. The partners also believe that they can do as they please and that is the reason why these kind of agreements tend to fail and ultimately, result in the collapse of the government before completion of its term, Lesotho is an example; as it is in the third coalition government. The two previous coalition governments failed to last five-year term period which resulted in the calling of early elections and the third coalition government, affectionately known as four by four by its supporters. This current coalition has now lasted for two years and it is gaining strength as some three opposition members of parliament have defected into the government side.

The issue of coalition governments being regarded as not legally enforceable lead to conflict within coalition partnerships because one or more parties can decide not to comply with the partnership commitments. This is because parties are unable to force other parties to abide by the rules. For instance, this is one of the reasons Kenya's NARC coalition was destabilised (Kadima, 2014:9). Failure of other parties to abide by the rules leads to loss of trust among the coalition partners and this can result in formation of new coalitions (Kadima and Owuor, 2006:212). In instances where partners or parties are not ideologically aligned, policymaking is the most controversial element of coalition agreements. The policies are likely to be vague and weak due to disconnected ideologies (Timmermans, 2003:8). To avoid weak and vague policies, coalition partners have to agree about as many of the major points of the policies as possible before going into government. Going into government without reaching an agreement on policies leads to a legislative deadlock (Timmermans, 2003:8). These kinds of policies complicate the implementation process. 
Coalition governments are said to be a means through which the incumbent presidents retain power through the back door. For instance, it is feared that coalition governments can lead to a trend where incumbent presidents decline to vacate office after losing elections, with the hope that there could be a power-sharing arrangement discussed with the opposition (Japeth, 2008:28). It can be agreed that when it comes to the case of Lesotho, the formation of the pre-2007 alliances were mainly based on the office-seeking theory, whereby the political elite used alliances to access and retain power. Kapa and Shale (2013: 95) stressed that the opposition parties are likely to dispute the election process and evoke violence in order to be incorporated into the government that may emerge. Another criticism levelled against coalitions is that coalition governments denote a failure of democracy; because the will of citizens is altered when political party leaders decide to resort to coalition governments (Mogeni, nd). For instance, in Kenya and Zimbabwe, opting for coalition governments was a way of approving the results of a flawed electoral process.

\section{Conclusion}

In relation to what has been demonstrated above, there is no model that is perfect for sustaining coalitions. This is because there are various issues that need to be revisited. Another issue that the political leaders have to bear in mind is that countries are different. Therefore, the coalition model cannot just be adopted because political leaders want to retain power, which is usually the case in African countries. Although this model is said to bring about unity within deeply divided societies, with it come a lot of complication with can lead to political instability, Lesotho is an example. In general, this model is not good for African countries.

\section{References}

Anderson, C. J. (2000). Economic voting and political context: a comparative perspective. Electoral Studies, 19(2):151-17. Andeweg, R. B. (2015). Consociatianalism. International Encyclopaedia of the Social and Behavioural Sciences, :692-694.

Baskaran, T, (2013). Coalition governments, cabinet size, and the common pool problem: Evidence from the German states. European Journal of Political Economy, 32(2013):356-376.

Booysen, S. (2015). The 2015 parliamentary elections in Lesotho. Electoral Studies, 40(2015):430-447.

Cheibub, J. A., Przeworski, A., \& Saiegh, S. M. (2004). Government coalitions and legislative success under presidentialism and parliamentarism. British Journal of Political Science, 34(4), 565-587.

Dhillon, A. (2003). Political Parties and Coalition Formation, Working Paper. Coverntry: university of Warwick, Department of Economics.

Fisher, S. D. and Hobolt, S. B. (2010). Coalition government and electoral accountability. Electoral Studies, 29(2010):358369.

Golder, S. (2006). Pre-electoral coalition formation in parliamentary democracies. British Journal of Political Science, 36(2006):193-212.

Hartzell, C. and Hoddie, M. (2015). Institutionalising peace: power sharing and post-civil war management. American Journal of Political Science, 47(2):318-332.

Helm, C. and Neugart, M. (2013). Coalition Governments and Policy Reform with Asymmetric Information. Journal of Institutional and Theoretical Economics, 169(3):383-406.

Henry, A. (2009). Kenya's Grand Coalition Government- Another Obstacle to Urgent Constitutional Reform? in Africa Spectrum, 44(3):149-164.

Higgins, B. (2014). Conceptualising Coalition Government development and Flaggship Programmes. India:

Horowits, D. (1991). A Democratic South Africa? Constitutional Engineering in a Divided Society, California: University of California Press.

Idasa. (2008). Negotiations, Democratic Space, and Zimbabwe's 2008 Elections. Research Advocacy Unit and States in Transition Observatory.

Japeth, B. (2008). The advent of unholy alliences? Coalition governments in the aftermath of disputed elections and electoral violence in Africa; a case study of Kenya. University of Western Cape.

Kadima, D. and Lembani, S. (2006). Making, Unmaking and Remaking Political Party Coalitions in Malawi: Explaining the Prevalence of Office-Seeking Behaviour in Kadima, D the Politics of Party Coalitions in Africa Johannesburg: EISA, KAS.

Kadima, D. and Owuor, F. (2006). The National Rainbow Coalition: Achievements and Challenges of Building and Sustaining a Broad-Based Political Party Coalition in Kenya in Kadima, D the Politics of Party Coalitions in Africa Johannesburg: EISA, KAS.

Kapa, M. A. and Shale, V. (2013). Alliance, Coalitions, and the Political System in Lesotho 2007-2012. Journal of African Elections, 13(1): 93-114.

Conference proceedings of the Centre for Business \& Economic Research, ICBED-2020, 20-22 August 
Karume, S. (2003). Conceptual understanding of political coalition in South Africa: an integration of concepts and practices. Electoral Institute of Southern Africa. Cape Town.

Kimani, N. (2017). Kenya: New opposition coalition formed to take on Kenyatta. Daily Maverick. https://www.dailymaverick.co.za/article/2017-01-26-kenya-new-opposition-coalition-formed-to-take-onkenyatta/. (Accessed on 12 April 2019).

Kisobo, J. J. (2013). The impact of coalition government on political, economic, and social development of post-conflict societies: case of Kenya, 2008-2012. University of Nairobi.

Laver, M. and Budge, I. (1992). Party policy and government coalitions. New York: Martin's Press.

Lijphart, A. (2013). Consociationalism. Taiwan Journal of Democracy, 87(101):87-102.

Lijphart, A. (2004). constitutional design for divided societies. Journal of Democracy, 15(3):96-106.

Majeed, A. (2000). Coalition Politics and power sharing. New Delhi: Manak Publishers.

Matjama, T. (2013). A Year of Coalition Government in Lesotho. https://matjama.wordpress.com/2013/08/03/a-year-ofcoalition-government-in-lesotho/ . (Accessed on 02 December 2018).

Mogeni, D. nd. New trend of power-sharing a threat to democracy. www.nation.co.ke/oped/opinion/-/440808/472328//31sw28/-/index.html. (Accessed on 01 December 2018).

Motsamai, D. (2012). Lesotho After May 2012 General Elections: Making the Coalition Work. Institute for Security Studies. https://issafrica.org/iss-taday/lesotho-after-may-2012-general-elections-making-the-coalition-work. (Accessed on 15 April 2019).

Moury, C., \& Timmermans, A. (2013). Inter-Party Conflict Management in Coalition Governments: Analyzing the Role of Coalition Agreements in Belgium, Germany, Italy, and the Netherlands. Politics and Governance, 1(2), 117-131.

Mutakha, J. (2007). Coalition governments and governments of national unity. Moi University Law Journal, 1(2):109120.

Oyugi, W. (2006). Coalition politics and coalition governments in Africa. Journal of Contemporary African Studies, 24(1):53-79.

Pippa, N. (2008). Driving Democracy: Do Power-Sharing Institutions Work? New York: Cambridge University press.

Rabushaka, A and Shepsle, K. A. (1972). Politics in plural societies: a theory of democratic instability. New York: Anchor Books.

Raman, P. K. (2001). Coalition Politics in India: A Review, in, Ram, S. 2001. Coalition Politics in India-A Search for Stability. New Delhi: National Publishing House.

Sithanen, R. (2003). Coalition politics under the tropics: office seekers, power makers, nation building: A case study of Mauritius. Paper presented at the EISA Roundtable on "Strengthening Democracy through Coalition Building". Vineyard Hotel: Cape Town.

Shin, E. A model of pre-electoral coalition formation. Games and Economic Behaviour, 102(2018):162-215.

Shodhganga. (2005). Towards Understanding Coalition Government.

shodhganga.inflibnet.ac.in/bitstream/10603/923/18/18_research. (Accessed on 01 December 2018).

Sisk, T. D. (1999). Power Sharing and International Mediation in Ethnic Conflicts. New York: Carnergie Cooperation.

South African History Online. 1994. South Africa's First Democratic Elections. https://www.sahistory.org.za/datedevent/south-africas-first-democratic-elections. (Accessed on 23 April 2019).

Timmermans, A. (2003). Standing Apart and Sitting Together: Enforcing Coalition Agreements in Multiparty Systems paper presented at the workshop The Morphology of Governments Annual Meeting of the Spanish Political Science and Public Administration Association (AECPA) in Barcelona

https://pdfs.semanticscholar.org/141d/b2a907eadab74db9f78c80a43dcf9c1e50b5.pdf (last accessed 2 May 2018).

Tiwana, S. S. (2001). Coalition Politics in India-Problems and Prospects, in, Ram, S. 2001. Coalition Politics in India-A Search for Stability. New Delhi: National Publishing House.

Vowels, J. (2010). Making a difference? Public perceptions of coalition, single-party, and minority governments. Electoral Studies. 29(2010):370-380. 